\title{
The Impact of Foreign Direct Investment Inflowson Balance of Payment
}

\author{
Lalit Kumar Bhardwaj, Rohit Sood, Gangu Naidu Mandala, K. Srinivasa Rao
}

\begin{abstract}
India with a powerful development rate is currently triumph more acclimatized with world economy. The cross outskirts are vague in a monetary market and have made influence on the Indian economy too. India after globalization has now supported the crosswise over outskirts trade and consequently has progressed with the monetary development. Moreover, we have tried to relationship exists between a portion of the factors like current account and merchandise and ventures, Foreign Direct Investment and between Capital account inflows. The examination explores the effect of Foreign Direct Investment on India's Balance of Payment for a time of 2012-2016 quarter savvy. Optional information will be made through RBI site, Journals, Research articles and papers. The investigation utilizes Regression to organize connection between dependent and free factors. Here foreign direct investment, the current and capital account as logical factors, while the balance of payments is the needy variable. The investigation is drawn for the balance of payments and a logical end is drawn for the connection of balance of payments with the free factors.
\end{abstract}

Keywords: Foreign Direct Investment, current account balance, capital account balance, balance of trade.

\section{INTRODUCTION TO FOREIGN DIRECT INVESTMENT - FDI}

Foreign direct investment (FDI) is an investment made by a firm or individual in one nation into business premiums situated in another nation. For the most part, FDI happens when a speculator builds up foreign business tasks or procures foreign business resources, including setting up proprietorship or controlling enthusiasm for a foreign organization. Foreign direct investments are recognized from portfolio investments in which a speculator simply buys values of foreign-based organizations ${ }^{1}$.

\section{MEANING OF BALANCE OF PAYMENTS}

Balance of payments is nations used to screen all global money related exchanges at occasionally. BOP is utilized to determined quarterly are every year for consistently. All trade led by both open and private part are accounted so as to decide how much cash is going all through the nation. The BOP essentially sorted into three classifications current, capital, money related account ${ }^{2-3}$.

Current account: The current account is utilized to keep up inflows and surges of a nation. With the current account all charges and credits of trade and stock of crude material, and

Revised Manuscript Received on November 15, 2019

Lalit Kumar Bhardwaj, Mittal School of Business, Lovely Professional University, Punjab, India,

Rohit Sood, Mittal School of Business, Lovely Professional University, Punjab, India,

Gangu Naidu Mandala, GITAM Institute of Management, GITAM Deemed to be University

K. Srinivasa Rao, GITAM Institute of Management, GITAM Deemed to be University assembling merchandise and ventures that are purchased and sold with rest of the world to comprehend the noteworthiness of the piece of BOP we should beginning of taking a gander at the parts of current account.

Capital account: the capital accounting monetary term it is a net change in investment and possession. Capital account is utilized to allot nations inflows and streams of private and open investments. This account is utilized to keep up nation's balance of Payments with current account. The capital account balances with foreign direct investment, foreign security investments and bank stores, and the nations save account. The capital account is utilized to keep up by the nation's national bank and used to keep up foreign securities to balance out nations' monetary forms.

Balance of trade: Balance of trade is the contrast between all imports and fares of products and enterprises of a nation for a timeframe. It is an apparatus that comprehends the nation's current account it clarifies if nation's fare is more than its import is known as trade excess. On the off chance that a nation's Import is more than its fare is known as trade deficiency.

Foreign direct investment: FDI is a key part of globalization. FDI is cross-country investment to make foreign undertaking in host nation and private endeavour in foreign nation, which makes work, and improve aptitudes of neighbourhood work through exchange of innovation and director learning and makes and incorporate the household economy with worldwide economy.

\section{REVIEW OF LITERATURE}

Dazzling Srivatsava (2016) examined the components that impact nations trade balance and found that there are different holes between trade among home nation and rest of the world. Government is taking different activities to enhance fare and decline import.

L. Kannan (2014) effect of Foreign Direct Investment in Imports and Exports and found that there is certain connection among FDI and Exports and Imports. FDI isn't the main logical measure for anticipating fares and imports. It is affect on both open and private part reciprocal trade and investment advancement as needs be.

Hossain, 2007. The monetary effect of FDI on the dimension of financial action has been broadly examined as of late crosswise over various nations. Results from studies recommend that FDI Inflows can pack in or swarm out local investment relying upon the explicit components of the economy. Be that as it may, by and large FDI positively affects financial development. The key factors in deciding the greatness of the effect included accessibility of assets, supply of human capital and so forth. 


\section{The Impact of Foreign Direct Investment Inflowson Balance of Payment}

Sahoo and Mathiyazhagan (2002) recommended that there is a long-run connection between Gross Domestic Product (GDP), FDI, and Export (EX) and furthermore contended that FDI does not make a difference in the development of the economy, however trade adds to the development in India. Out of the few examinations focussing looking into the issue of creating nations, lion's share of them reasons that FDI has critical positive effect on monetary development.

Sen, 1995 As of late, nonetheless, the gloss has worn to some degree thin on this medicine, basically because of developing experimental proof which recommend that FDI may have an increasingly positive effect on the BOP of the starting nation than on that of the beneficiary nation The exact perception that profits on FDI often climb steeply after an underlying time of unprofitability proposes that FDI ought not for the most part be seen as a methods for financing Balance of Payments needs over the medium term Data Analysis

Table: 01demonstrates the development in current and capital account for a time of 14 quarters from 2013-2017

\begin{tabular}{|c|c|c|c|c|}
\hline Year & $\begin{array}{c}\text { Current } \\
\text { Account }\end{array}$ & $\begin{array}{c}\text { Current } \\
\text { Account } \\
\text { Growth }\end{array}$ & $\begin{array}{c}\text { Capital } \\
\text { Account }\end{array}$ & Capital Account Growth \\
\hline $2013-2014 \mathrm{Q} 1$ & -886 & & -10 & $-74 \%$ \\
\hline $2013-2014 \mathrm{Q} 2$ & -1232 & $-39 \%$ & -17 & $103 \%$ \\
\hline $2013-2014 \mathrm{Q} 3$ & $-1,767$ & $-43 \%$ & 1 & $-1393 \%$ \\
\hline $2013-2014 \mathrm{Q} 4$ & -979 & $45 \%$ & 8 & $-427 \%$ \\
\hline $2014-2015 \mathrm{Q} 1$ & 1,218 & $-24 \%$ & 43 & $132 \%$ \\
\hline $2014-2015 \mathrm{Q} 2$ & -1158 & $5 \%$ & -14 & $150 \%$ \\
\hline $2014-2015 \mathrm{Q} 3$ & -262 & $77 \%$ & 7 & $239 \%$ \\
\hline $2014-2015 \mathrm{Q} 4$ & -75 & $71 \%$ & -9 & $111 \%$ \\
\hline $2015-2016 \mathrm{Q} 1$ & -469 & $-527 \%$ & 1 & $183 \%$ \\
\hline $2015-2016 \mathrm{Q} 2$ & -612 & $-31 \%$ & -1 & $-223 \%$ \\
\hline $2015-2016 \mathrm{Q} 3$ & -509 & $17 \%$ & -3 & $-372 \%$ \\
\hline $2015-2016 \mathrm{Q} 4$ & -80 & $84 \%$ & -13 & $104 \%$ \\
\hline $2016-2017 \mathrm{Q} 1$ & -392 & $-390 \%$ & 0 & $45 \%$ \\
\hline $2016-2017 \mathrm{Q} 2$ & -534 & $-36 \%$ & 0 & \\
\hline
\end{tabular}

Predictors : Foreign Direct investment

The above table: $\mathbf{0 1}$ and chart demonstrates the development in current and capital account for a time of 14 quarters from 2013-2017. The information examination above demonstrates the rate change in capital and current account for a time of 14 quarters. The normal development is $-46 \%$ in current account and

\section{OBJECTIVES}

The main objective is to show the relation between current account and balance of trade and capital account and FDI and how its effect on balance of payment of a country.

\section{RESEARCH METHODOLOGY}

Research procedure is an investigation of concentrate how inquire about is to be done. Basically, the techniques by which specialists approach their work of depicting, clarifying and foreseeing marvels are called examine philosophy. It is likewise characterized as the investigation of techniques by which information is picked up.

The paper is based on secondary data, which collected various sources like RBI, Investopedia, and Trading economics etc. The paper is majorly in descriptive in nature.

Table: 02:the synopsis for balance of trade and current account

\begin{tabular}{|l|l|l|l|l|l|}
\hline Model & Multiple R & $\begin{array}{l}\text { R } \\
\text { Square }\end{array}$ & $\begin{array}{l}\text { Adjusted } \\
\text { Square }\end{array}$ & $\begin{array}{l}\text { Standard } \\
\text { Error }\end{array}$ & Significance \\
\hline $\begin{array}{l}\text { Balance of } \\
\text { Trade }\end{array}$ & 0.993594736 & $\begin{array}{l}0.987230 \\
498\end{array}$ & 0.986318391 & 55.45658647 & $0.000^{*}$ \\
\hline
\end{tabular}

Predictor's Balance of trade

Dependent variable : Current Account

* At $95 \%$ confidence level.

The table:02 above clarifies the synopsis for balance of trade and current account. The R esteem clarifies the connection estimation of balance of trade and current account which is 0.99 that portrays there is flawlessly positive relationship between's balance of trade and current account. R2 decides the quality between two factors current account and Balance of Trade, R2 esteem is 0.98, which

demonstrates factually critical. Beta esteems 1.04, which means there is impeccable relationship. $\mathrm{P}$ esteem 0.000 which is $<0.05$ at $95 \%$ certainty level, henceforth invalid theory dismissed and induce that there is criticalness connection between balance of trade and current account.

capital account is $-115 \%$. The most noteworthy in current account shortfall is recorded in the year 2016-2017Q4 and the least is recorded in the year 2013-2014Q3. The capital account is recorded most astounding in the year 43 in the year 2014-2015Q1 and the minimum in the year 2013-2014Q2. 
Table: 03the outline for Foreign Direct Investment and Capital Account

\begin{tabular}{|c|c|c|c|c|c|}
\hline Model & Multiple R & R Square & $\begin{array}{c}\text { Adjusted R } \\
\text { Square }\end{array}$ & $\begin{array}{c}\text { Standard } \\
\text { Error }\end{array}$ & Significance \\
\hline FDI & 0.0528299 & 0.0027910 & -0.068438209 & 14.1157883 & 0.8459311 \\
\hline $\begin{array}{c}\text { Capital } \\
\text { Account }\end{array}$ & & 05 & & 4 & 56 \\
\hline
\end{tabular}

Predictors : Foreign Direct investment

Dependent variable : Capital Account

The table: $\mathbf{0 3}$ above clarify the outline for Foreign Direct Investment and Capital Account. The $\mathrm{R}$ esteem clarifies the relationship esteem Foreign Direct Investment and Capital Account of which is 0.052 that delineates there is no positive connection between's Foreign Direct Investment and Capital Account. R2 decides the quality between two factors Capital Account and Foreign Direct Investment, R2 esteem is 0.00279, which demonstrates measurably not noteworthy. $\mathrm{P}$ esteem: 0.845 at $95 \%$ certainty level, subsequently invalid theory acknowledged and derive that there is no noteworthiness connection between Foreign Direct Investment and Capital Account.

\section{CONCLUSION}

In this examination paper, the investigation of Balance of Payment is made with the examination of Current account and Capital account. The examination was made by utilizing Regression investigation between Current account and Balance of Trade account. The examination demonstrates to us that there is a critical relationship of Current account to the Balance of trade with Beta incentive as 1.04, Regression esteem is 0.99 and $\mathrm{R}$ square esteem is 0.987 with Significance esteem 0.000. This infers the Balance of trade strongly affects Current account. Currently the Current account is in shortfall yet on a declining mode. Balance of trade having a solid affiliation can be utilized as a noteworthy apparatus to control the shortage and decline the shortfall further.

The investigation for Capital account was likewise made regarding Foreign Direct Investment utilizing Regression examination. The investigation demonstrates that there is no noteworthy relationship in the middle of Capital account and Foreign Direct Investments with Beta incentive as - 0.00403, Regression esteem is 0.052 and $R$ square esteem is 0.0027 with Significance esteem 0.8459 . Henceforth, further research must be carried on to discover the elements, which have solid relationship with Capital account, as Foreign Direct Investment does not influence the Capital account. Currently Capital account is in surplus with a development rate of $40 \%$ in Q4 of 2016-17. Thus, examination of variables other than Foreign Direct Investments must be made to discover factors with positive affiliation, which can be utilized as device for enhancing the Capital Account development rate.

\section{REFERENCES}

1. Dibeh, G., Foreign Aid and Economic Development in Post-war Lebanon, Foreign Aid for Development: Issues, Challenges, and the New Agenda, May 01, 2010, ISBN: 978-019172334-6;978019958093-4

2. Mandala, G.N., Kakkar, R., A study on impact of exchange rate factor on Indian stock market, A study on impact of exchange rate factor on Indian stock market, Journal of Computational and Theoretical Nanoscience, Volume 16, Issue 5-6, 2019, Pages 21282130.

3. Naidu, M.G., Babu, P.R., Raju, V.I, A study on applications of return and risk-adjusted theoretical parameters of mutual funds in India, International Journal of Applied Business and Economic Research, Volume 12, Issue 4, 2014, Pages 997-1016.

4. Seguino, S., Gender, distribution, and balance of payments constrained growth in developing countries, Review of Political Economy, Volume 22, Issue 3, 2010, Pages 373-404.

5. Hutchison, M.M., Noy, I., Wang, L., Fiscal and monetary policies and the cost of sudden stops, Journal of International Money and Finance Volume 29, Issue 6, October 2010, Pages 973-987.

6. Sen, Pronab. (1995). Foreign Direct Investment: A Solution to BOP Problems? Economic and Political Weekly, Vol. 30, No. 30 (Jul. 29, 1995).Retrieved https://www.epw.in/special-articles/foreign-directinvestment-solution-bop-problems.html Websites

7. https://rbi.org.in/scripts/SDDS_ViewDetails.aspx?Id=5\&IndexTitle $=$ Balance+of+payment, balance of payment in India.

8. https://tradingeconomics.com/india/balance-of-trade, A Trend analysis of Trade imbalances of Indian balance of payment.

9. https://tradingeconomics.com/india/balance-of-trade, Analysis of trends in the balance of payments in India.

10. https://tradingeconomics.com/india/balance-of-trade, Comparative analysis of Balance of Payments: Indian perspective 